\title{
Rising water temperatures, reproduction and recruitment of an invasive oyster, Crassostrea gigas, on the French Atlantic coast
}

\author{
Mickaël Dutertre $^{\mathbf{a},{ }^{*}}$, Peter G. Beninger ${ }^{\mathbf{a}}$, Laurent Barillé ${ }^{a}$, Mathias Papin ${ }^{\mathbf{b}}$ and Joël Haure ${ }^{\mathbf{b}}$ \\ a Université de Nantes, Nantes Atlantique Universités, Équipe Mer-Molécules-Santé EA 2160, Faculté des \\ Sciences et des Techniques, 2 rue de la Houssinière, BP 92208, Nantes 44322, France \\ ${ }^{b}$ IFREMER, Laboratoire Conchylicole des Pays de la Loire, Polder des Champs, Bouin 85230, France \\ *: Corresponding author: M. Dutertre, Tel.: +33 02511256 91; fax: +33 02511256 68, email address : \\ Mickael.Dutertre@univ-nantes.fr
}

\begin{abstract}
:
The recent appearance and invasion of feral oysters (Crassostrea gigas) along the northern European Atlantic coast, underscores the necessity to investigate the relationship between environmental variables, reproductive physiology, larval development and recruitment. We studied these relationships at both high (HT) and intermediate (IT) - turbidity sites, through historical data on water temperatures, multi-parameter environmental probes, histological analyses, and field collections of planktonic larvae and settled post-larvae in 2005 and 2006. A progressive warming trend was observed, especially since 1995, when oyster proliferation first became severe. Threshold temperatures for oocyte growth, larval development and settlement were achieved in both 2005 and 2006. The HT site showed greater numbers of larvae and post-larvae than the IT site for both years, with the highest numbers of post-larvae observed at both sites during the warmer summer of 2006. These results suggest that increased temperatures in northern European waters allow successful reproduction, larval development, and recruitment of $C$. gigas. High turbidity conditions further enhance this success.
\end{abstract}

Keywords: Aquaculture; Climate warming; Coastal waters; Crassostrea gigas; Reproductive cycle; Oyster larvae; Settlement; Turbidity

\section{Introduction}

Suspension-feeding bivalves are coastal ecosystem engineers that regulate matter and energy fluxes by coupling pelagic and benthic processes (see Dame and 
Olenin, 2005 for reviews). In the twentieth century, over-exploitation, pollution, and disease led to a worldwide decline in native oyster populations, accompanied by economic losses and ecological changes (Newell, 1988; Quayle, 1988; Ruesink et al., 2005). The Pacific cupped oyster, Crassostrea gigas, was voluntarily introduced in several new coastal areas around the world for aquaculture purposes, because of its rapid growth rate, high tolerance to environmental variations and low susceptibility to oyster diseases (Coleman, 1986; Smith et al., 1986; Grizel and Héral, 1991).

Although successful introductions of $C$. gigas occurred particularly in northern temperate countries of Europe and North America, water temperatures precluded substantial larval recruitment in the northernmost regions (Le Borgne et al., 1973; Gruet et al., 1976; Goulletquer, 1995; Drinkwaard, 1999). France is a particularly interesting case, since the occurrence of massive and regular feral $C$. gigas recruitments in the southern Atlantic regions, but not in the northern ones, suggested that the limit for the successful larval development was situated south of Bourgneuf Bay (Goulletquer and Héral, 1991; Robert and Gérard, 1999). However, in the past decade, feral oysters have proliferated on northern European Atlantic coasts, unrelated to new introductions, and $C$. gigas is now considered to be an invasive organism from Spain to the North Sea (Reise et al., 1999; Wehrmann et al., 2000; Cognie et al., 2006; Brandt et al., 2008). This phenomenon is particularly visible in northern French turbid bays, where the feral $C$. gigas build long-lasting reefs and colonize racks on which are attached farmed C. gigas bags (Martin et al., 2004; 2005). In these areas, trophic competition with feral oysters has been suggested to explain the decline in farmed oyster growth performance in the last ten years (Cognie et al., 2006). Although reproduction performances of farmed adult oysters are being 
elucidated (Dutertre et al., in revision), field studies on natural recruitment are also necessary to understand the recent feral oyster invasion (Underwood and Fairweather, 1989; Grosberg and Levitan, 1992; Smaal et al., 2005).

Optimal larval development of $C$. gigas requires a water temperature higher than $22^{\circ} \mathrm{C}$ during at least two weeks (Arakawa, 1990; Shatkin et al., 1997; Rico-Villa et al., 2008) and oyster larvae are affected by food quality and quantity (Baldwin and Newell, 1995; Powell et al., 2002; Rico-Villa et al., 2008). As larval survival is the determining element for the settlement of feral oyster populations (Gosling, 2003), environmental influences on larval development need to be clarified by field studies, especially in turbid coastal waters which are characterized by seasonal and shortterm variations of the environmental conditions (Mann, 1982).

In an attempt to determine the causes of the recent invasion of feral oysters, in northern cold temperate ecosystems, the present study analyzed the larval development and post-larval recruitment of $C$. gigas at the southern and northern geographic extremes of Bourgneuf Bay in relation to real-time monitored environmental factors.

\section{Materials and methods}

\subsection{Adult oyster sampling and tissue fixation}

Feral and farmed oysters were collected at two oyster-farming sites in Bourgneuf Bay, between February 2005 and July 2006 (Fig. 1, Haure and Baud, 1995). The northern site, La Coupelasse $\left(47^{\circ} 1^{\prime} 34.7^{\prime \prime} \mathrm{N}, 2^{\circ} 1^{\prime} 55.9^{\prime \prime} \mathrm{W}\right)$, is a high - 
turbidity mudflat compared to the southern sandy-muddy bottom site, Gresseloup $\left(46^{\circ} 57^{\prime} 2.6^{\prime \prime} \mathrm{N}, 2^{\circ} 7^{\prime} 53.4^{\prime \prime} \mathrm{W}\right)$.

At the beginning of the study, in February 2005, adult farmed oysters (shell length $=69.2 \pm 4.9 \mathrm{SD} \mathrm{mm}$, originating from 18-month hatchery-born spats,) were installed, at both the northern and southern sites, in $1.0 \times 0.5 \mathrm{~m}$ plastic, $20 \mathrm{~mm}$ mesh bags and tied to oyster racks $(3.0 \times 1.0 \mathrm{~m})$ at $0.6 \mathrm{~m}$ above the bottom. Each bag contained 280 individuals, corresponding to 5 - $10 \mathrm{~kg}$ of oysters. At each site, 15 farmed and 15 feral oysters were then sampled once monthly until March 2006 and then twice monthly until July 2006. Feral oysters, in the same range of shell length as farmed ones, were collected near oyster racks on fixed substrata. For each oyster, shell dimensions (length, width and height) were measured with a caliper and whole mass was determined before shucking. Soft tissues were then immediately fixed in cold aqueous Bouin's solution (approx. $5 \mathrm{x}$ animal volume) for at least two weeks (Beninger et al., 2001).

\subsection{Histological preparation}

After fixation, a $0.5 \mathrm{~mm}$-thick slice of the visceral mass was removed from the region along the line connecting the left and right palp-gill junctions (Morales-Alamo and Mann, 1989). The tissue was rinsed under running water overnight to eliminate excess Bouin's solution, dehydrated and prepared for paraffin embedding.

Embedded tissues were sliced with a microtome to obtain 10 histological sections per individual, $7 \mu \mathrm{m}$ in thickness. These sections were rehydrated, stained with modified Masson's trichrome and dehydrated before being mounted on glass slides in 
112 mounting medium (Beninger et al., 2001). Mounted histological sections were then 113 dried at $60^{\circ} \mathrm{C}$ for at least one week.

\subsection{Microscopic determinations and oocyte size measurements}

Oyster larvae are characterized by an initial endotrophic stage (utilization of

117 stored oocyte reserves), followed by a mixotrophic stage (oocyte reserves + ingested particles) and finally an exotrophic stage (ingested particles only - Lucas et al., 1986; His and Seaman, 1992; Cannuel and Beninger, 2005). Oocytes increase in size during vitellogenesis, so the relative amount of oocyte reserves was therefore estimated by measuring oocyte sizes in histological sections of female oysters, observed on a computer screen connected to a video camera (Nikon DXM 1200F) and optical microscope (Olympus AX70). LUCIA 4.80 software (Image Analysis Systems) was used to measure oocyte area showing sections passing through both the clear nucleus and a least one nucleolus ( $n=30$ per oyster). Oocyte diameter was then calculated as follows:

Oocyte diameter $(\mu \mathrm{m})=2 \times \sqrt{ }\left(\right.$ oocyte area $\left.\left(\mu \mathrm{m}^{2}\right) / \pi\right)$

Monthly means ( $\pm 95 \%$ confidence intervals, $\mathrm{Cl}$ ) of oocyte diameters were calculated and used to determine the gonadal development stage (Lango-Reynoso et al., 2000): early gametogenesis (3.0 to $12.0 \mu \mathrm{m})$, growing (12.1 to $30.0 \mu \mathrm{m})$, mature (30.1 to $41.0 \mu \mathrm{m})$ or atretic $(41.1$ to $60 \mu \mathrm{m})$. 


\subsection{Determinations of D-larva and post-larval densities}

Unambiguous identification of C. gigas larvae was achieved through a preliminary inventory of larval bivalve species at the two study sites, followed by identification using literature data (Rees, 1950; Le Pennec, 1978; His, 1991) and computer image analysis of key shell characteristics (Lucia G 4.80 software).

During known oyster spawning periods, plankton samples were collected at the northern and southern sites using a boat-mounted pump provided with a flowmeter. Each plankton sample $\left(1.5 \mathrm{~m}^{3}\right)$ was fixed in $10 \%$ formaldehyde - seawater solution and prepared for analysis as in Auby et al. (2002). Each sample was manually homogenized with a loop-ended glass stick to avoid damage to larvae, and two 0.5 $\mathrm{ml}$ aliquots were transferred to Sedgewick-Rafter counting cells and observed using a light microscope (Olympus AX70) in order to determine D-larva densities (shell height $=57$ to $105 \mu \mathrm{m}$; Rees, 1950; Le Pennec, 1978; His, 1991).

At each site, clusters of 10 striated tubular collectors (commonly used as substrata for oyster spat settlement in the field; length $=120 \mathrm{~cm}$, diameter $=2 \mathrm{~cm}$ ) were tied side by side to oyster racks $(3.0 \times 1.0 \mathrm{~m})$ at $0.6 \mathrm{~m}$ from the bottom. The clusters were rolled up at the end of each tidal cycle to count the post-larval (i.e. recently-settled spats) density, and replaced with new clusters for the next tidal cycle.

\subsection{Environmental monitoring}

Multi-parameter water quality probes (YSI 6600) were fixed to oyster racks installed at each sampling site, to record temperature $\left({ }^{\circ} \mathrm{C}\right)$, salinity (from conductivity), suspended particulate matter (SPM) concentration (nephelometry, 
NTU) and chlorophyll-a (chl-a) concentration (fluorometry, \%) every hour. The corresponding monthly means were plotted with their $95 \%$ confidence intervals $(n=$ 720).

Food is implicitly defined as ingestible matter. Since we do not know what, precisely, the oysters are ingesting, we can only use indicators of available food. These must take into account:

Quantity

Suspended Particulate Matter - the total amount of particles, quality not specified Particulate Organic Matter (POM) - potentially digestible particles, but quality not specified

Chlorophyll-a - amount of available phytoplankton, proportion of the available particulate matter not specified

Quality

POM:SPM - an indication of the organic content of the SPM (dilution of POM)

Chl-a:POM - an indication of the quality of the organic matter

In order to characterize potential food amount, availability, and quality, field calibrations for suspended matter were performed simultaneously from both probe records and natural seawater samples collected at each oyster sampling site over two tidal cycles. Some seawater samples $(n=17)$ were dried at $60^{\circ} \mathrm{C}$ for $48 \mathrm{~h}$ and then ashed at $450^{\circ} \mathrm{C}$ for $4 \mathrm{~h}$ (Barillé-Boyer et al., 2003) to obtain SPM and POM concentrations $\left(\mathrm{mg.l}^{-1}\right)$ respectively, while other samples $(n=16)$ were analyzed by spectrophotometry after extraction with acetone (Lorenzen, 1967) to determine chl-a 
179 concentrations $\left(\mu \mathrm{g} \cdot \mathrm{I}^{-1}\right)$. Linear regressions obtained from field samples were used to 180 transform hourly probe records into concentrations as follows:

SPM $\left(m g . l^{-1}\right)=1.44 \times$ turbidity $($ NTU $)+12.92, n=17, r^{2}=0.93$

POM $\left(m g . l^{-1}\right)=0.18 \times$ turbidity $(\mathrm{NTU})+3.42, \mathrm{n}=17, \mathrm{r}^{2}=0.94$

Chl- $a\left(\mu \mathrm{g} \mathrm{I}^{-1}\right)=4.63 \times$ fluorometry $(\%)+1.65, \mathrm{n}=16, \mathrm{r}^{2}=0.92$

Food dilution and quality, herein estimated as percent organic content of SPM were calculated as follows:

Chl-a:POM $(\%)=\left(\right.$ chl-a $\left(\right.$ mg. $\left.I^{-1}\right) /$ POM $\left.\left(m g . I^{-1}\right)\right) \times 100$

\subsection{Historical data of water temperature} January 1970 and December 2006, using the following regression (Haure and Baud, 1995):

$\mathrm{WT}=0.8703 \times \mathrm{AT}+0.036 \times \mathrm{TC}-0.0969$

Daily atmospheric temperatures (AT) were obtained from Météo-France's

Climathèque database (Noirmoutier station, 2915'24' 'W, 4700'18' $\mathrm{N}$ ) and tidal coefficients (TC) using the Marées dans le monde 2.02@ software. 


\subsection{Statistical analysis}

Sigmastat 3.1 (Systat software) was used to check the normality and heteroscedasticity of data distributions and then to perform statistical analyses. Temporal and spatial variations of environmental factors were compared by Student t-tests or two-way parametric ANOVA, while correlation between them was determined by Spearman correlation tests. Analyses of data from histological determinations, as well as larval and post-larval cumulative densities, were first performed with two-way parametric ANOVA within each reproductive cycle, and a posteriori by Student-Newman-Keuls (SNK) tests.

\section{Results}

\subsection{Environmental variations}

\subsubsection{Seston quantity and quality}

Over the sampling period, SPM, POM and chl-a concentrations were always higher at the HT site compared to the IT site (Fig. 2A, B and C - two-way ANOVA, $p<$ 0.01). The monthly mean POM:SPM ratio, used to estimate potential food dilution, was lower at the HT site in 2005 and 2006 (Fig. 3A, t-test, $p<0.01$ ). On the other hand, the monthly mean chl-a:POM ratio, used to estimate food quality, was higher at the HT site in 2005 (Fig. 3B, t-test, $p<0.01$ ), while no significant difference between sites was reported in 2006 (Fig. 3B, t-test, $p=0.98$ ).

3.1.2. Fine-scale variations of water temperature and salinity: $2005-2006$ 
Monthly mean water temperatures, largely typical of a northern temperate nearshore ecosystem, were not significantly different between the sites in 2005 and 2006 (Fig. 2D, Student t-test, $p=0.95$ and $p=0.99$, respectively). However, the summer period was warmer in 2006 vs. 2005, especially in July, where the mean water temperature was $1.5^{\circ} \mathrm{C}$ higher (Fig. 2D). The d aily amplitude of water temperature was higher at the HT site (Table 1, two-way ANOVA, $p<0.01$ ). Monthly mean salinity, ranging from 29.0 to 35.3 , was not significantly different between the sites in 2005 and 2006 (Student t-test, $p=0.93$ and $p=0.10$, respectively).

\subsubsection{Historical variations in water temperature}

Historical annual mean and warmest-month calculated mean water temperatures are presented for Bourgneuf Bay from 1970 - 2006 (Fig. 4). For the 17year period from 1970 - 1987, annual means were higher than the annual medians for only 2 years (11.8\%), versus 15 years (83.3\%) for the 18-year period from $1988-$ 2006. This situation prevailed in 10 of 11 years (91\%) from 1995 - 2006. Similarly, the warmest month means over the 17-year period from 1970 - 1987 were above the threshold temperature for successful reproduction $\left(20^{\circ} \mathrm{C}\right.$ - Chávez-Villalba et al., 2002; Rico-Villa et al., 2008) only 2 years (11.8\%), whereas over the 18 -year period from $1988-2006$, this situation prevailed in 9 years $(50 \%)$.

\subsection{Microscopic determinations and oocyte size}

Variations in oocyte size allowed identification of two distinct seasonal reproductive cycles in 2005 and 2006 (Fig. 5). In 2005, no significant difference was 
observed for mean oocyte diameter in intra-site (two-way ANOVA, $p=0.85$ ) and inter-site (two-way ANOVA, $p=0.81$ ) comparisons. Similarly, in 2006, no significant difference was observed for mean oocyte diameter in intra-site (two-way ANOVA, $p=$ 0.84 ) and inter-site (two-way ANOVA, $p=0.94$ ) comparisons. In both years, the oocyte growth stage began in the same periods (end of March - beginning of April). However, the mature stage, corresponding to the dominance of ready-to-spawn postvitellogenetic oocytes in the gonads, was reached more quickly in 2006 than in 2005 (two vs. three months). Gonads entered a degenerating stage (evidence of atresia in unspawned oocytes such as cell size increase and clearer cytoplasm - Dutertre et al., in revision), more prematurely in 2006 than in 2005 (July vs. August, respectively).

\subsection{D-larva and post-larval densities}

Cumulative D-larva densities showed significant differences related to both year and site (Figs. 6 and 7, two-way ANOVA, $p<0.05$ and $p<0.01$, respectively).

Cumulative D-larva densities were higher at the HT site for both years (SNK-tests, $p$ $<0.05$ for 2005 and $p<0.01$ for 2006). For the IT site, cumulative D-larva densities were higher in 2006 compared to 2005 (SNK-test, $p<0.05$ ), while, for the HT site, no significant differences were observed between the two years (SNK-test, $p=0.30$ ). At both sites, D-larvae appeared at the same periods: over two months in 2005, from the beginning of July to the beginning of September, with a marked increase of the planktonic larva densities observed at the end of August at the HT site. In 2006, the HT site showed two main peaks of planktonic larva densities, at the end of July and 
at the beginning of August, while, at the same periods, two smaller peaks of D-larva densities were recorded at the IT site.

Cumulative natural post-larval recruitment also showed significant differences related to both year and site (Figs. 6 and 7, two-way ANOVA, $p<0.01$ ). Natural recruitment was much higher in 2006 compared to 2005 at both sites (SNK-tests, $p<$ 0.001 for the HT site and $p<0.05$ for the IT site). Inter-site differences in the monthly post-larval counts were also evident, with proportionately higher counts at the HT site in both 2005 and 2006 .

\section{Discussion}

\subsection{Water temperature and recent oyster invasion}

At approximately 28000 t, the feral oyster stock in Bourgneuf Bay equals $70 \%$ of the annual farmed oyster production (Cognie et al., 2004; Martin et al., 2004; 2005). Water temperature variations, since the introduction of $C$. gigas for aquaculture, clearly show that the onset of the feral oyster invasion coincided with a marked water warming (Fig. 4). Indeed, between 1970 and 1995, when annual mean water temperature was usually lower than the median temperature $\left(13.4^{\circ} \mathrm{C}\right)$, cumulative feral oyster recruitment was very low (Le Borgne et al., 1973; Gruet et al., 1976; Goulletquer, 1995). Massive recruitment of feral oysters, observed since 1995 (Cognie et al., 2006) corresponded to the beginning of the period where summer months often showed water temperature higher than $20^{\circ} \mathrm{C}$, which is required for successful C. gigas larval development in hatcheries (Arakawa, 1990; Shatkin et al., 1997; Chávez-Villalba et al., 2002; Rico-Villa et al., 2008). These quantitative 
historical data thus support earlier hypotheses of a relationship between C. gigas proliferation in cool temperate European ecosystems and global warming (Diederich et al., 2005; Ruesink et al., 2005; Smaal et al., 2005). Among the temperaturerelated variables which could contribute to this proliferation are those which chiefly affect larval survival and subsequent recruitment of feral oysters: oocyte reserves, spawning period and seston conditions (Baldwin and Newell, 1995; Powell et al., 2002; Chávez-Villalba et al., 2003; Rico-Villa et al., 2008).

\subsection{Oocyte fate timed by water temperature thresholds}

During two successive reproductive cycles of $C$. gigas, oocyte diameter variations showed that the field reproductive cycle was timed by discrete water temperature thresholds (Dutertre et al., in revision). The oocyte growing stage, characterized by both an increase in size and in vittelin reserves (see Gosling, 2003 for recent review), began when spring water temperature reached $8-10^{\circ} \mathrm{C}$. The mature stage was reached more quickly in 2006 than in 2005 (two vs. three months), corresponding to a reduced daily amplitude of water temperatures in 2006, and also to a greater energy level of breeders due to higher spring food quality (chl-a:POM ratio) and/or recovery of energy from the large amount of reabsorbed atretic oocytes at the end of summer 2005 (Dutertre et al., in revision). Although early partial spawns could be detected when daily variations in water temperature briefly exceeded $18^{\circ} \mathrm{C}$, water temperatures of $15-18^{\circ} \mathrm{C}$ cause mature, unspa wned oocytes to enter atresia (Dutertre et al. in revision). Major spawning activities were recorded when summer water temperature, higher than $20^{\circ} \mathrm{C}$, could efficien tly sustain C. gigas larval development (Chávez-Villalba et al., 2002; Rico-Villa et al., 2008). 
Similar oocyte size in farmed and feral oysters at both sites indicated that future fertilized eggs would contain equivalent amounts of vitellus for the endotrophic and mixotrophic larval stages (Lucas et al., 1986; His and Seaman, 1992; Cannuel and Beninger, 2005). This result is in agreement with the observation that variations in reproductive effort in $C$. gigas reflect variations in gamete quantity rather than quality (Caers et al., 2002; Chávez-Villalba et al. 2003; Cannuel and Beninger, 2005).

\subsection{Planktonic larval life}

Maximal planktonic larva densities in the water column were observed during defined summer periods in which high oyster fecundity was synchronized with a water temperature higher than $20-2^{\circ} \mathrm{C}$. D-larva de nsities corresponded to the patterns of breeder spawning strategy at both sites in 2005 and 2006, but early amply compensated by the sheer amount of food available for the larvae.

\subsection{Feral oyster recruitment}

Natural post-larval recruitment at both HT and IT sites was much higher in 2006 (4540 and 1489 annual settled post-larvae. $\mathrm{m}^{-2}$, respectively) compared to 2005 (45 
and 4 annual settled post-larvae. $\mathrm{m}^{-2}$, respectively). Although 2006 could be considered an exceptionally favorable year for oyster reproduction and post-larval recruitment in relation to the warmer summer temperatures, natural recruitment in Bourgneuf Bay remained very low compared to more southern coastal ecosystems. Indeed, the best natural recruitments in Arcachon Bay over the past twenty years were reported in 2003 and 2006 with more than 60000 settled post-larvae. $\mathrm{m}^{-2}$ of limed tiles (Auby et al., 2006). Environmental conditions at the HT site, notably the chlorophyll-a levels, regardless of the organic matter dilution, appear to promote local feral oyster recruitment. This is confirmed by oyster-farmer practices over the past several years, which preferentially use the HT site to install artificial spat collectors (Marion Petit, Section Régionale Conchylicole, Bouin, France, pers. com.). Once established, large feral oyster reefs can disrupt flow, limit larval dispersal, and offer substrate for settlement, enhancing local post-larval recruitment at the HT site.

\section{Conclusion}

The historical data presented here clearly show that $C$. gigas proliferation in the Bourgneuf Bay ecosystem corresponds to warmer water temperatures, particularly since 1995. A similar evolution in water temperatures has been recorded at more northerly sites (Wadden Sea), also corresponding to increasing C. gigas recruitment (Diederich et al, 2005). The underlying processes of reproduction and development are acutely sensitive to such warming through the threshold temperatures of oocyte growth and larval development, and ultimately greater recruitment of post-larval feral oysters, as shown by the recent fine-scale temporal data of the present study. A continuation of the warming trend in water temperatures 
362 should thus produce an intensification of this proliferation, and a range extension

363 northward in shallow European bays, including those used for oyster farming. Given

364 the now near-ubiquitous distribution of $C$. gigas in temperate coastal habitats, these

365 observations should serve to alert the marine environment research community to

366 potentially similar situations worldwide.

\section{Acknowledgements}

369 We thank David Lecossois for the installation of the animals used in this study in oyster bags at his farm, and Odile Aumaille for technical assistance in histological

371 analyses. Research funding was provided by the Syndicat Mixte pour le

372 Développement de l'Aquaculture et de la Pêche (SMIDAP) de la Région des Pays de

373 la Loire, and M. Dutertre was supported by a PhD scholarship from the Ministère

374 Français de la Recherche et de l'Enseignement Supérieur. 


\section{References}

Arakawa, K.Y., 1990. Natural spat collecting in the Pacific oyster Crassostrea gigas (Thunberg). Marine Behavior and Physiology 17, 95-128.

Auby, I., Maurer, D., Valvason, M.L., Gueguen, C., Guillard, F., 2002. Mise au point d'une nouvelle méthode de suivi de la reproduction de l'huître creuse: Comparaison avec la méthode traditionnelle. Rapport Direction de l'Environnement et de l'Aménagement du Littoral. IFREMER RST.DEL/02.01/ARCACHON.

Auby, I., Maurer, D., Cassam-Chenai, Y., Tournaire, M.-P., Neaud-Masson, N., Rumèbe, M., Cantin, C., Debort, H., Germain, J.-M., Navarro, R. 2006. Reproduction de l'huître creuse dans le Bassin d'Arcachon: Année 2006. Rapport Direction de l'Environnement et de l'Aménagement du Littoral. IFREMER RST/LER/AR/06-006.

Baldwin, B.S., Newell, R.I.E., 1995. Feeding rate responses of oyster larvae (Crassostrea virginica) to seston quantity and composition. Journal of Experimental Marine Biology and Ecology 189, 77-91.

Barillé, L., Haure, J., Cognie, B., Leroy, A., 2000. Variations in pallial organ and eulatero-frontal cirri in response to high particulate matter concentrations in the oyster Crassostrea gigas. Canadian Journal of Fisheries and Aquatic Sciences $57,837-843$.

Barillé-Boyer, A.-L., Barillé, L., Massé, H., Razet, D., Héral, M., 2003. Correction for particulate organic matter as estimated by loss on ignition in estuarine ecosystems. Estuarine, Coastal and Shelf Science 58, 147-153. 
Beninger, P.G., Cannuel, R., Blin, J.-L., Pien, S., Richard, O., 2001. Reproductive characteristics of the archaeogastropod Megathura crenulata. Journal of Shellfish Research 20, 301-307.

Brandt, G., Wehrmann, A., Wirtz, K.W., 2008. Rapid invasion of Crassostrea gigas into the German Wadden Sea dominated by larval supply. Journal of Sea Research 59, 279-296.

Caers, M., Utting, S.D., Coutteau, P., Millican, P.F., Sorgeloos, P., 2002. Impact of the supplementation of a docosahexaenoic acid-rich emulsion on the reproductive output of oyster broodstock, Crassostrea gigas. Marine Biology $140,1157-1166$.

Cannuel, R., Beninger, P.G., 2005. Is oyster broodstock feeding always necessary? A study using oocyte quality predictors and validators in Crassostrea gigas. Aquatic Living Resources 18, 35-43.

Chávez-Villalba, J., Barret, J., Mingant, C., Cochard, J.C., Le Pennec, M., 2002. Autumn conditioning of the oyster Crassostrea gigas: A new approach. Aquaculture 210, 171-186.

Chávez-Villalba, J., Cochard, J.C., Le Pennec, M., Barret, J., Enríquez-Díaz, M., Cáceres-Martínez, C., 2003. Effects of temperature and feeding regimes on gametogenesis and larval production in the oyster Crassostrea gigas. Journal of Shellfish Research 22(3), 721-731.

Cognie, B., Barillé, L., Carrié, C., Rosa, P., 2004. Estimation des stocks d'huîtres sauvages en baie de Bourgneuf (partie Loire-Atlantique). Rapport de contrat Région des Pays de la Loire, arrêté n02-5923-0 du 19 mars 2002, 19 pp. 
422 Cognie, B., Haure, J., Barillé, L., 2006. Spatial distribution in a temperate coastal ecosystem of the wild stock of the farmed oyster Crassostrea gigas (Thunberg). Aquaculture 259, 249-259.

425

Coleman, N., 1986. A review of introductions of the Pacific oyster (Crassostrea gigas) around the world and a discussion of the possible ecological consequences of introducing the species into Victoria, Australia. Marine Resources Man and Wildlife Service, Department of Conservation, Forests and Lands, Queescliff,Victoria, Australia, 39 pp.

Dame, R.F., Olenin, S., 2005. The comparative roles of suspension-feeders in ecosystems. NATO Science Series. IV. Earth and Environmental Sciences vol. 47, Springer, $359 \mathrm{pp}$.

Diederich, S., Nehls, G., van Beusekom, J.E.E., Reise, K., 2005. Introduced Pacific oysters (Crassostrea gigas) in the northern Wadden Sea: invasion accelerated by warm summers? Helgoland Marine Research 59, 97-106.

Drinkwaard, A.C., 1999. Introductions and developments of oysters in the North Sea area: a review. Helgoland Meeresunters 52, 301-308.

Dutertre, M., Beninger, P.G., Barillé, L., Papin, M., Rosa, P., Barillé, A.-L., Haure, J., in revision. Temperature and seston quantity and quality effects on field reproduction of farmed oysters, Crassostrea gigas, in Bourgneuf Bay, France. Aquatic Living Resources

Gosling, E., 2003. Reproduction, Settlement and Recruitment. In:Bivalve molluscs: biology, ecology and culture. Gosling E. (ed.), Fishing News Books, Blackwell Science, Oxford, 131-168. 
Goulletquer, P., 1995. Cycle de reproduction naturelle de l'huître creuse Crassostrea gigas. Groupe de travail sur la Reproduction des Mollusques Bivalves d'Aquaculture Marine, IFREMER, Nantes, France.

Goulletquer, P., Héral, M., 1991. Aquaculture of Crassostrea gigas in France. The ecology of C. gigas in Australia, New Zealand, France and Washington State. Oyster Ecology Workshop, Annapolis, USA, 12-19.

Grizel, H., Héral, M., 1991. Introduction into France of the Japanese oyster (Crassostrea gigas). Journal du Conseil International pour l'Exploration de la Mer, 47, 399-403.

Grosberg, R.K., Levitan, D.R., 1992. For adults only? Supply-side ecology and the history of larval biology. Trends in Ecology and Evolution 7(4), 130-133.

Gruet, Y., Héral, M., Robert, J.M., 1976. Premières observations sur l'introduction de la faune associée au naissain d'huîtres japonaises Crassostrea gigas (Thunberg), importé sur la côte atlantique française. Cahiers de Biologie Marine $17,173-184$.

Haure, J., Baud, J.P., 1995. Approche de la capacité trophique dans un bassin ostréicole (baie de Bourgneuf). Rapport Direction Ressources Vivantes IFREMER RIDVR-95-96/RA-BOUIN.

His, E., 1991. Biologie et écotoxicologie des véligères de Crassostrea gigas (Thunberg) dans le Bassin d'Arcachon. PhD thesis, University of Bordeaux I, France.

His, E., Seaman, M.N.L., 1992. Effects of temporary starvation on the survival, and on subsequent feeding and growth, of oyster (Crassostrea gigas) larvae. Marine Biology 114, 277-279. 
Lango-Reynoso, F., Chávez-Villalba, J., Cochard, J.-C., Le Pennec, M., 2000. Oocyte size, a means to evaluate the gametogenic development of the Pacific oyster, Crassostrea gigas (Thunberg). Aquaculture 190, 183-199.

Le Borgne, M., Gras, M.P., Comps, M., Carruesco, G., Razet, D., 1973. Observations sur la reproduction des huîtres dans la Seudre (Bassin de Marennes-Oléron) en 1972. 5 pp.

Le Pennec, M., 1978. Genèse de la coquille larvaire et postlarvaire chez divers bivalves marins. PhD thesis, University of Bretagne Occidentale, France.

Lorenzen, C.J., 1967. Determination of chlorophyll and pheopigments:

Spectrophotometric equations. Limnology and Oceanography 12, 343-346.

Lucas, A., Chebab-Chalabi, L., Aldana Aranda, D., 1986. Passage de l'endotrophie à l'exotrophie chez les larves de Mytilus edulis. Oceanologica Acta 9(1), 97-103.

Mann, K.H., 1982. Ecology of coastal waters: a systems approach. Studies in ecology, vol. 8, Univ. California Press, Berkeley, 322 pp.

Martin, J.L., Haure, J., Dupuy, B., Papin, M., Palvadeau H., Nourry, M., Penisson, C., Thouard, E. 2004. Estimation des stocks d'huîtres sauvages sur les zones concédées de la partie vendéenne de la baie de Bourgneuf en 2003. Rapport IFREMER, DRV/RA/LCPL/2004-05, 21 pp.

Martin J.L., Haure J., Dupuy, B., Papin, M., Palvadeau, H., Nourry, M., Penisson, C., Thouard, E., 2005. Estimation des stocks d'huîtres sauvages sur les zones non concédées de la partie vendéenne de la baie de Bourgneuf. Rapport IFREMER, AGS/LGP/Bouin/2005-01, 17pp. 
Morales-Alamo, R., Mann, R., 1989. Anatomical features in histological sections of Crassostrea virginica (Gmelin, 1791) as an aid in measurements of gonad area for reproductive assessment. Journal of Shellfish Research 8, 71-82.

Newell, R.I.E., 1988. Ecological changes in Chesapeake Bay: are they the results of overharvesting the American oyster, Crassostrea virginica? Chesapeake Research Consortium Publications 129, 536-546.

Powell, E.N., Bochenek, E.A., Klinck, J.M., Hofmann, E.E., 2002. Influence of food quality and quantity on the growth and development of Crassostrea gigas larvae: a modelling approach. Aquaculture 210, 89-117.

Quayle, D.B., 1988. Pacific oyster culture in British Columbia. Canadian Bulletin of Fisheries and Aquatic Sciences 218, 1-24.

Reise, K., Gollasch, S., Wolff, W., 1999. Introduced marine species of the North Sea coasts. Helgoland Marine Research 52, 219-234.

Rees, C.B., 1950. The identification and classification of lamellibranch larvae. Hull Bulletins of Marine Ecology 3(19), pp. 73-104.

Rico-Villa, B., Pouvreau, S., Robert, R., 2008. Influence of food density and temperature on ingestion, growth and settlement of Pacific oyster larvae, Crassostrea gigas. Aquaculture 287, 395-401.

Robert, R., Gérard, A., 1999. Bivalve hatchery technology: the current situation for the Pacific oyster Crassostrea gigas and the scallop Pecten maximus in France. Aquatic Living Resources 12, 121-130. 
512 Ruesink, J.L., Lenihan, H.S., Trimble, A.C., Heiman, K.W., Micheli, F., Byers, J.E., 513 Kay, M.C., 2005. Introduction of non-native oysters: ecosystem effects and 514 restoration implications. Annual Review of Ecology, Evolution and Systematics $36,643-689$.

Shatkin, G., Shumway, S.E., Hawes, R., 1997. Considerations regarding the possible introduction of the Pacific oyster (Crassostrea gigas) to the Gulf of Maine: a review of global experience. Journal of Shellfish Research 16, 463-477.

Smaal, A., van Stralen, M., Craeymeersch, J., 2005. Does the introduction of the Pacific oyster Crassostrea gigas lead to species shifts in the wadden sea? In:

Smith, P.J., Ozaki, H., Fujio, Y., 1986. No evidence for reduced genetic variation in the accidentally introduced oyster Crassostrea gigas in New Zealand. New Zealand Journal of Marine and Freshwater Research 20, 569-574.

Underwood, A.J., Fairweather, P.G., 1989. Supply-side ecology and benthic marine assemblages. Trends in Ecology and Evolution 4(1), 16-20.

Wehrmann, A., Herlyn, M., Bungenstock, F., Hertweck, G., Millat, G., 2000. The distribution gap is closed-first record of naturally settled Pacific oysters (Crassostrea gigas) in the East Frisian Wadden Sea, North Sea. Senckenbergiana Maritima 30, 153-160. 
533 Table 1. Mean daily amplitudes ( \pm SD) of water temperature at the northern high

534 turbidity (HT, La Coupelasse) and southern intermediate turbidity (IT, Gresseloup)

535 sites of Bourgneuf Bay in 2005 and 2006.

\begin{tabular}{llll}
\hline & Year & n (days) & $\begin{array}{l}\text { Amplitude of water } \\
\text { temperature ('C) }\end{array}$ \\
\hline HT site & 2005 & 278 & $3.43 \pm 2.01$ \\
& 2006 & 349 & $2.23 \pm 1.40$ \\
IT site & 2005 & 251 & $2.39 \pm 1.63$ \\
& 2006 & 347 & $1.78 \pm 1.29$ \\
\hline
\end{tabular}

536

537 


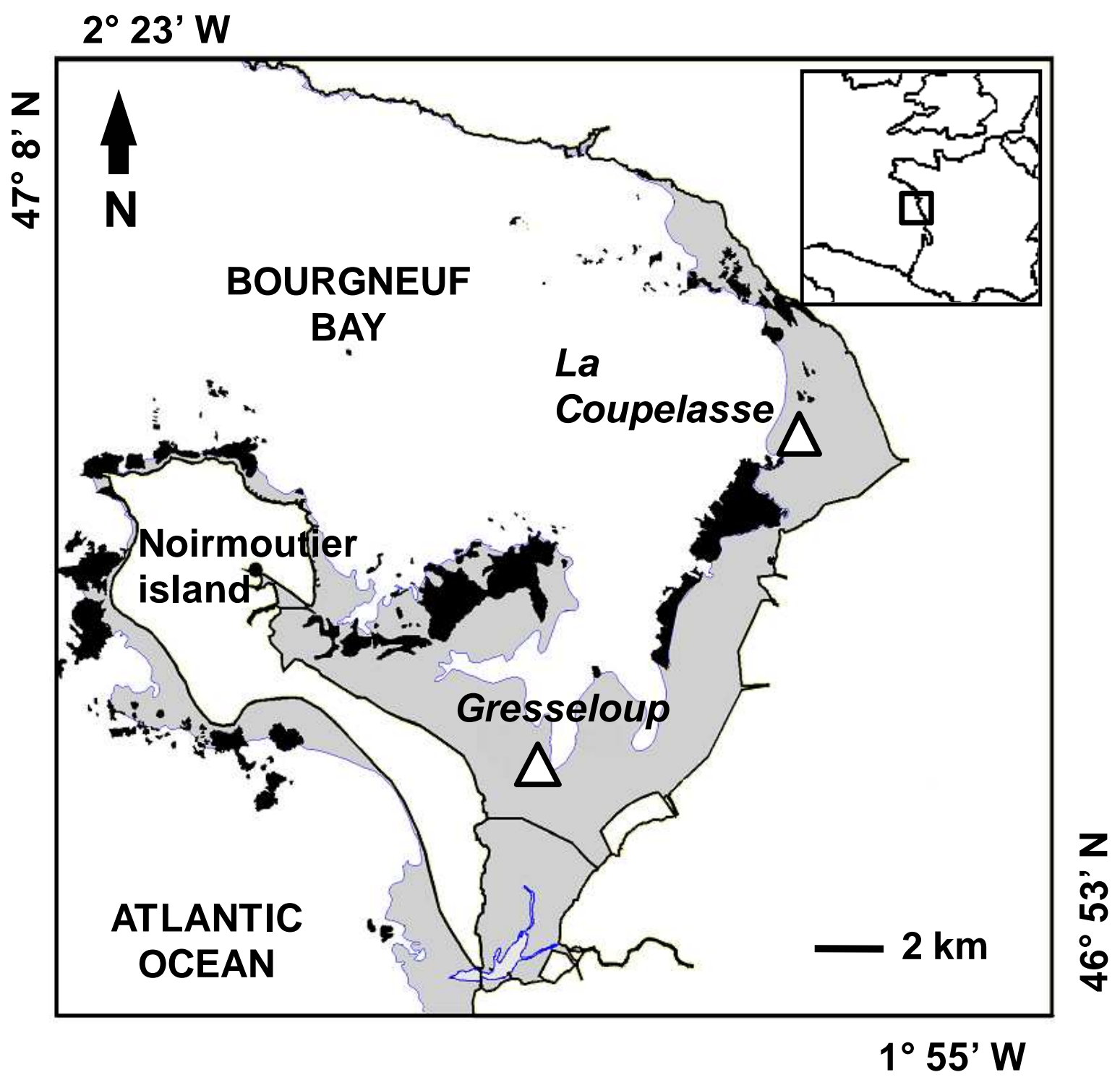

Fig. 1. Location of northern (La Coupelasse) and southern (Gresseloup) oyster

540 sampling sites $(\boldsymbol{\Delta})$ in Bourgneuf Bay. The intertidal zone and rocks are represented by gray and black areas respectively (modified from Barillé et al., 2000). 

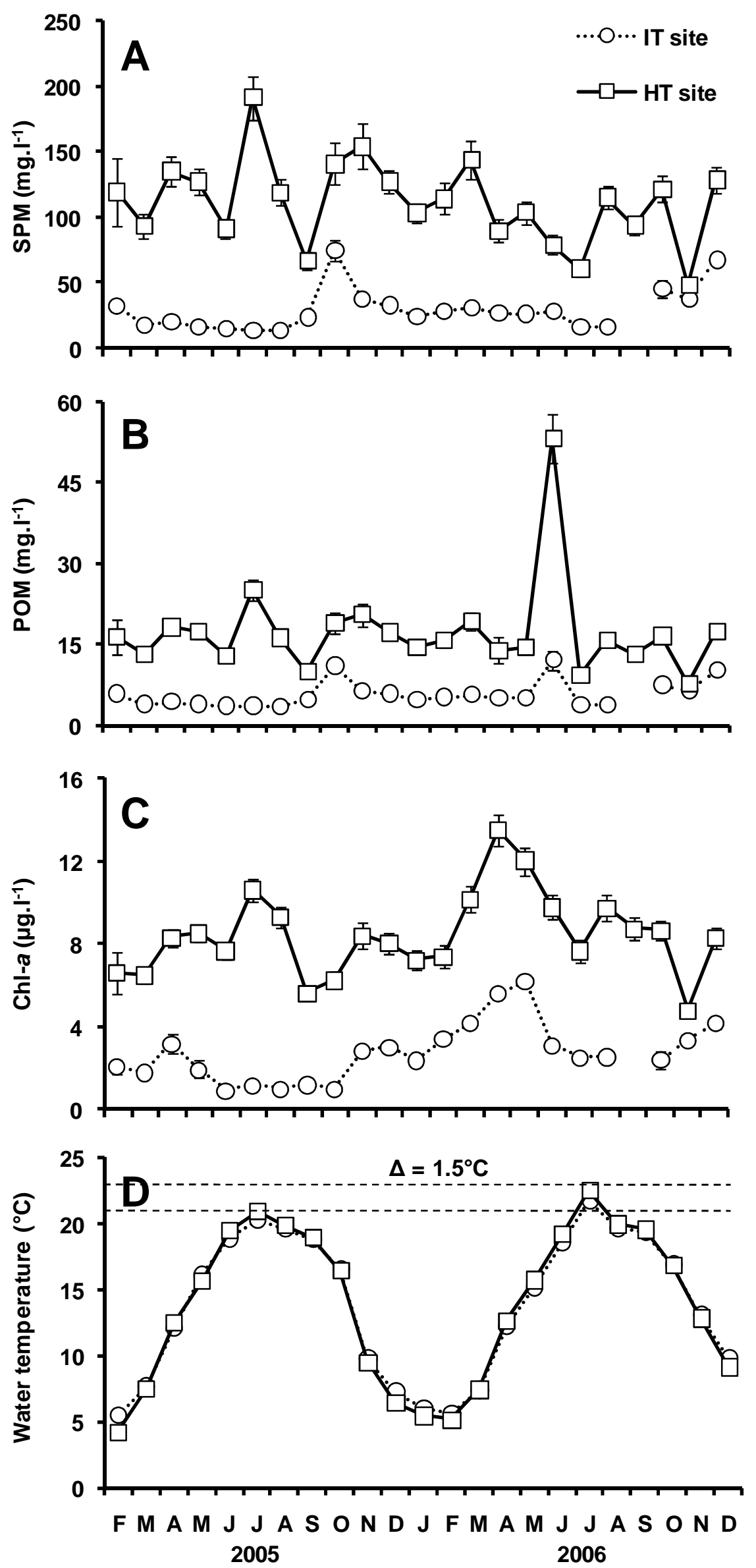
543 Fig. 2. Variations of suspended particulate matter (SPM, A), particulate organic

544 matter (POM, B) and chlorophyll-a (chl-a, C) concentrations, and water temperature

545 (D) at the northern high turbidity (HT) and southern intermediate turbidity (IT) sites of

546 Bourgneuf Bay, in 2005 and 2006. Means $\pm 95 \%$ confidence intervals. 

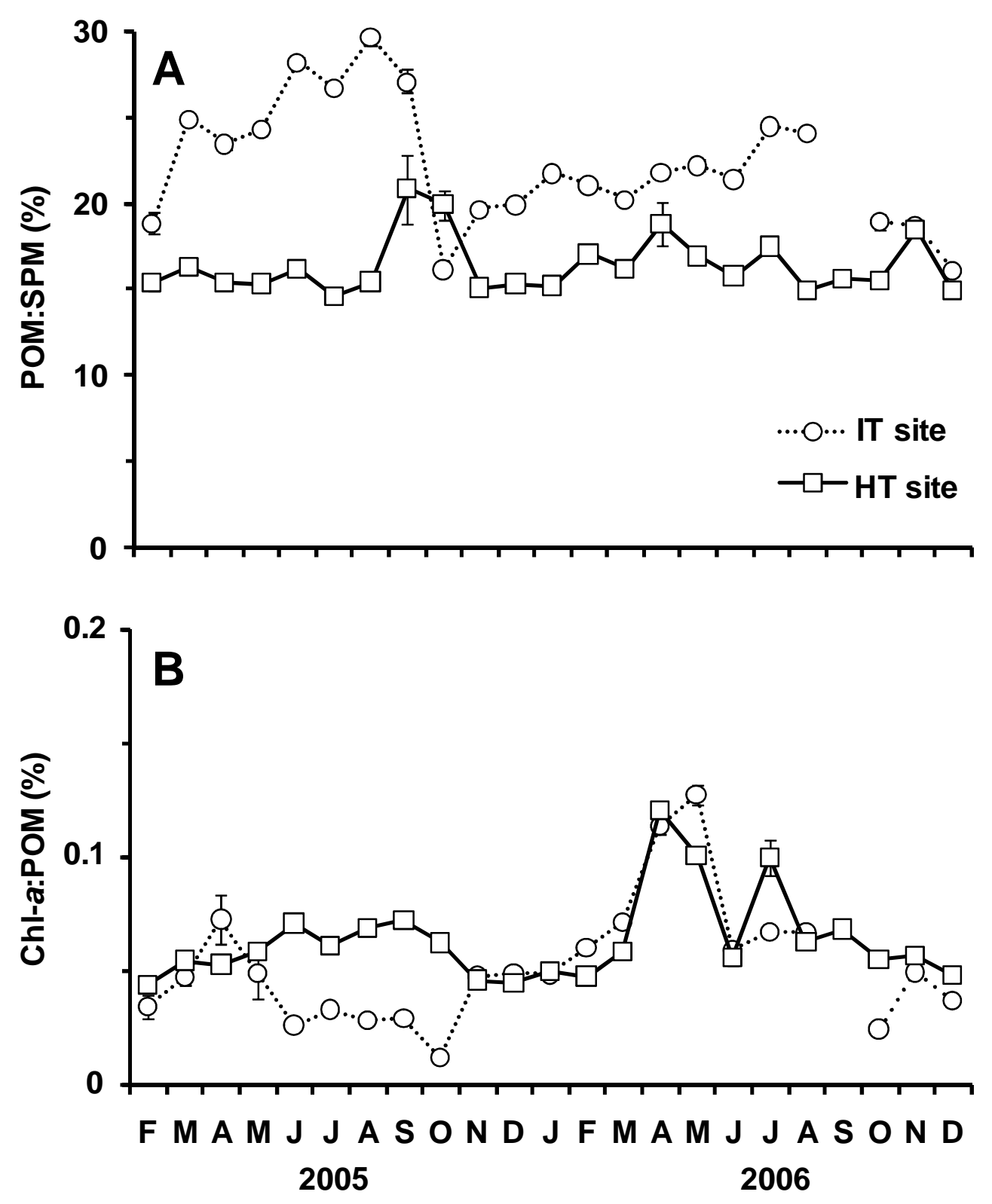

548 Fig. 3. Dilution (POM:SPM, A) and quality (chl-a:POM, B) of organic particles at 549 northern high turbidity (HT) and southern intermediate turbidity (IT) sites of

550 Bourgneuf Bay in 2005 and 2006. Chl-a: chlorophyll-a, POM: particulate organic 551 matter, SPM: suspended particulate matter. Means $\pm 95 \%$ confidence intervals. 


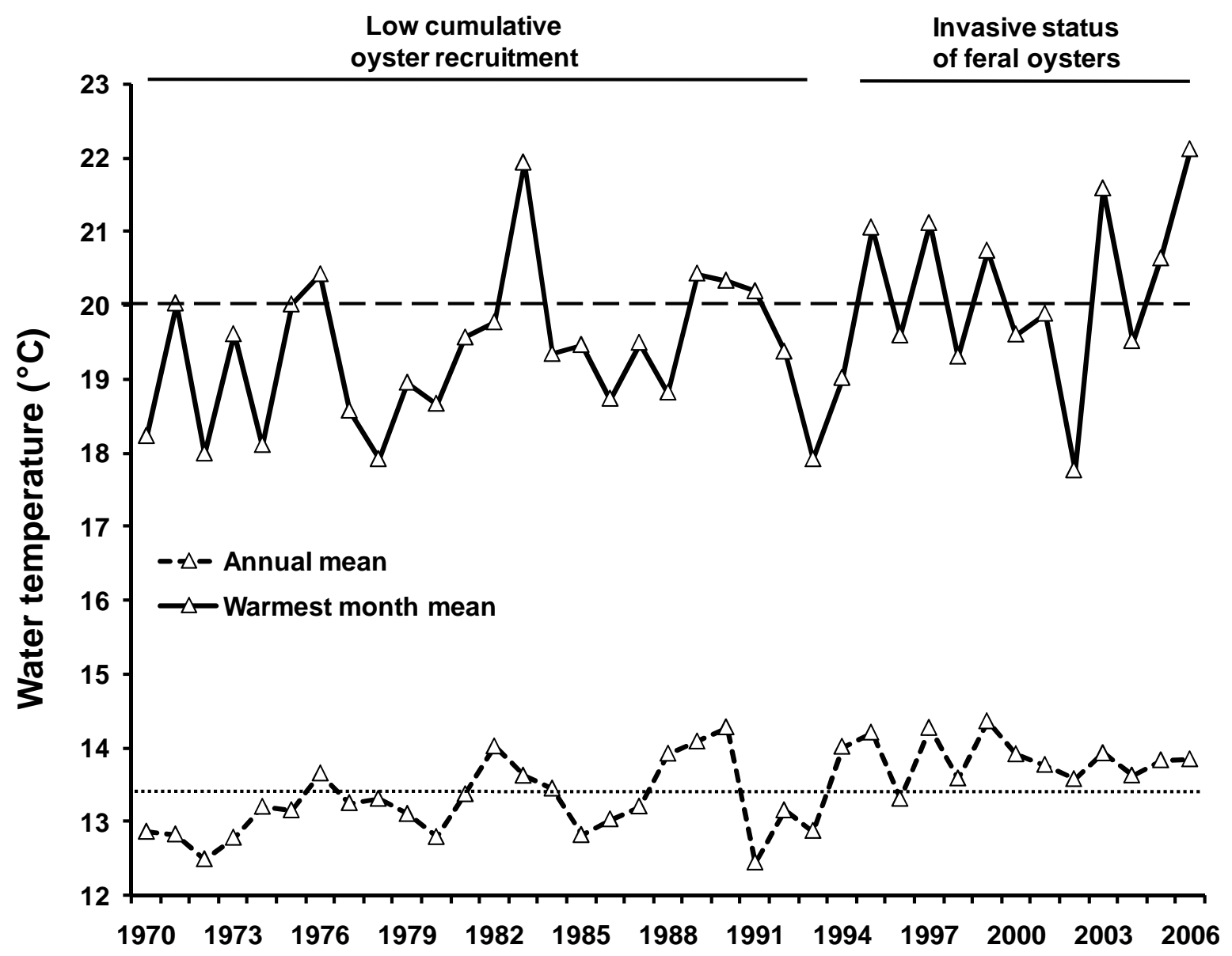

553 Fig. 4. Annual mean and warmest month mean of water temperature since the

554 introduction of Crassostrea gigas in the 1970's (Météo-France, Climathèque

555 database, Noirmoutier, 2007), and relationship with the natural recruitment of feral

556 oysters in Bourgneuf Bay (Goulletquer, 1995; Cognie et al., 2004; 2006; Martin et al.,

$5572004 ; 2005)$. Dotted line corresponds to the median temperature $\left(13.4^{\circ} \mathrm{C}\right)$ of annual

558 mean water temperature, dashed line corresponds to the minimal threshold $\left(20^{\circ} \mathrm{C}\right)$

559 for optimal C. gigas larval development. 

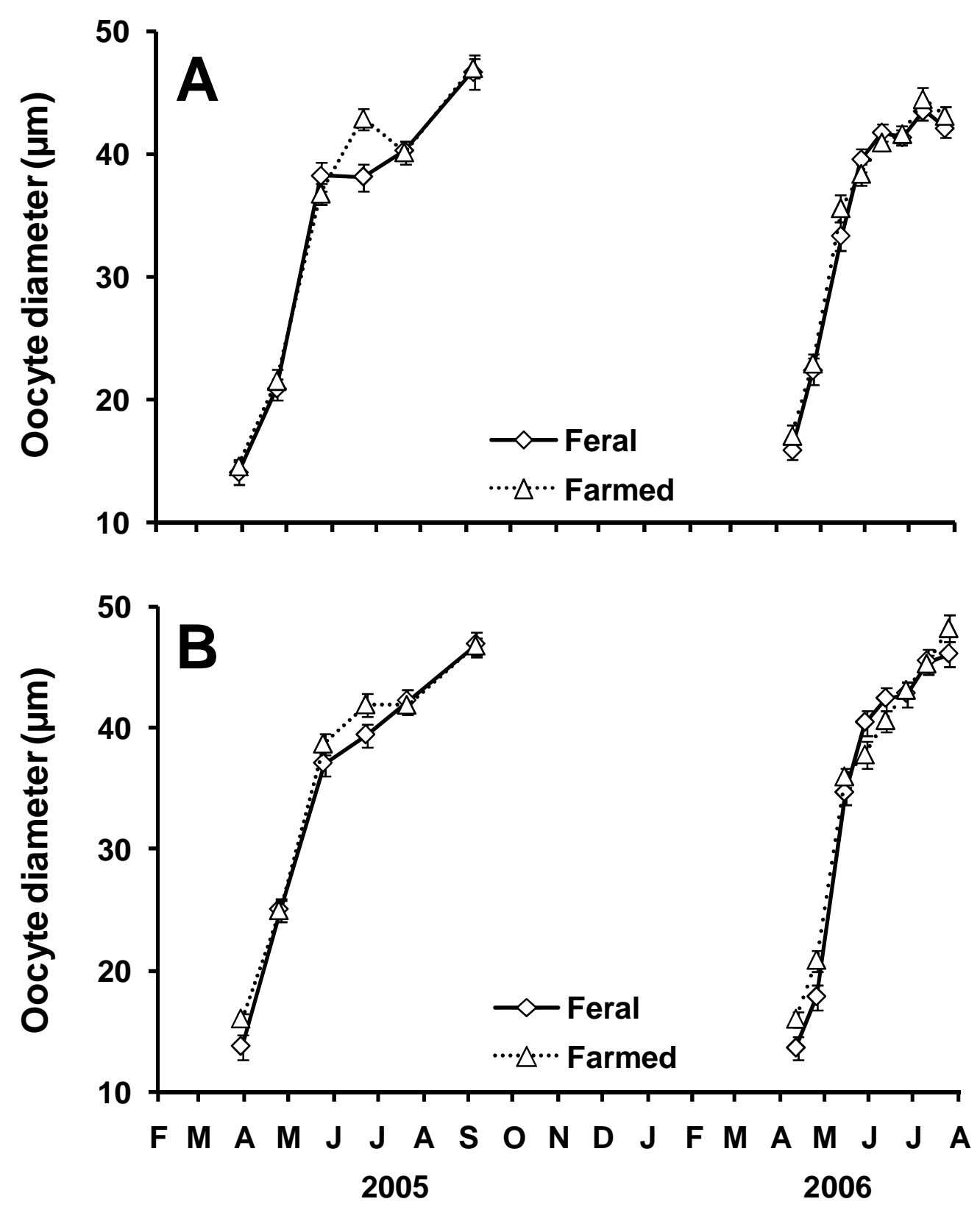

560

561 Fig. 5. Mean oocyte diameters ( $\pm 95 \%$ IC) for feral and farmed oysters, Crassostrea

562 gigas, at northern high turbidity (HT, A) and southern intermediate turbidity (IT, B)

563 sites of Bourgneuf Bay in 2005 and 2006. 
HT site
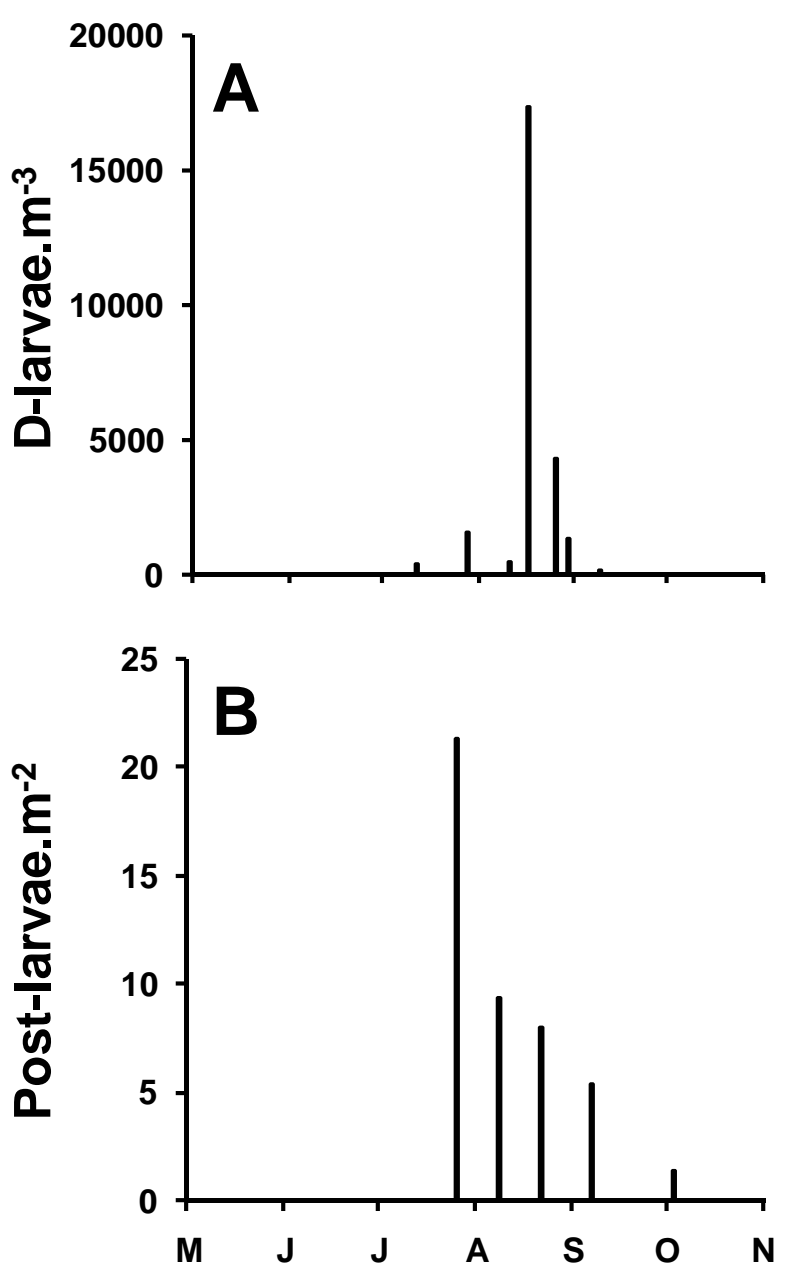

IT site
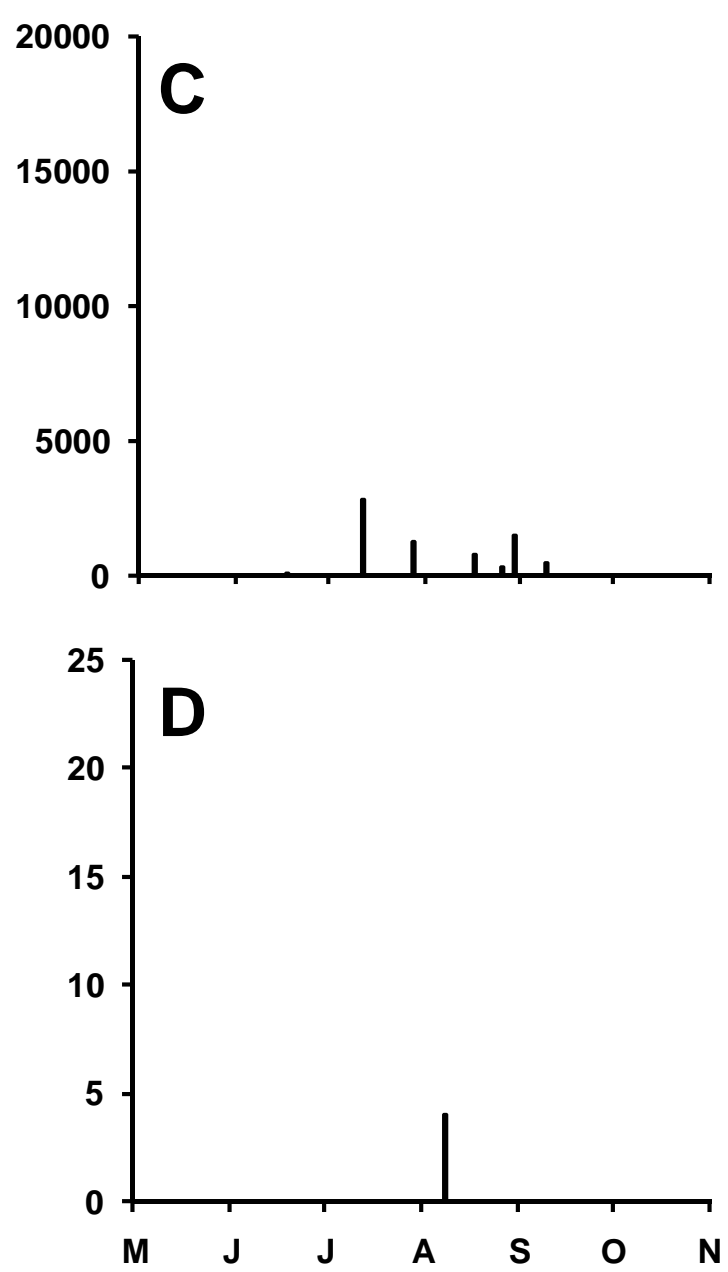

Fig. 6. D-larva $(A, C)$ and post-larval $(B, D)$ densities at the northern high turbidity

$566(\mathrm{HT})$ and southern intermediate turbidity (IT) sites of Bourgneuf Bay for the year 5672005. 


\section{HT site}
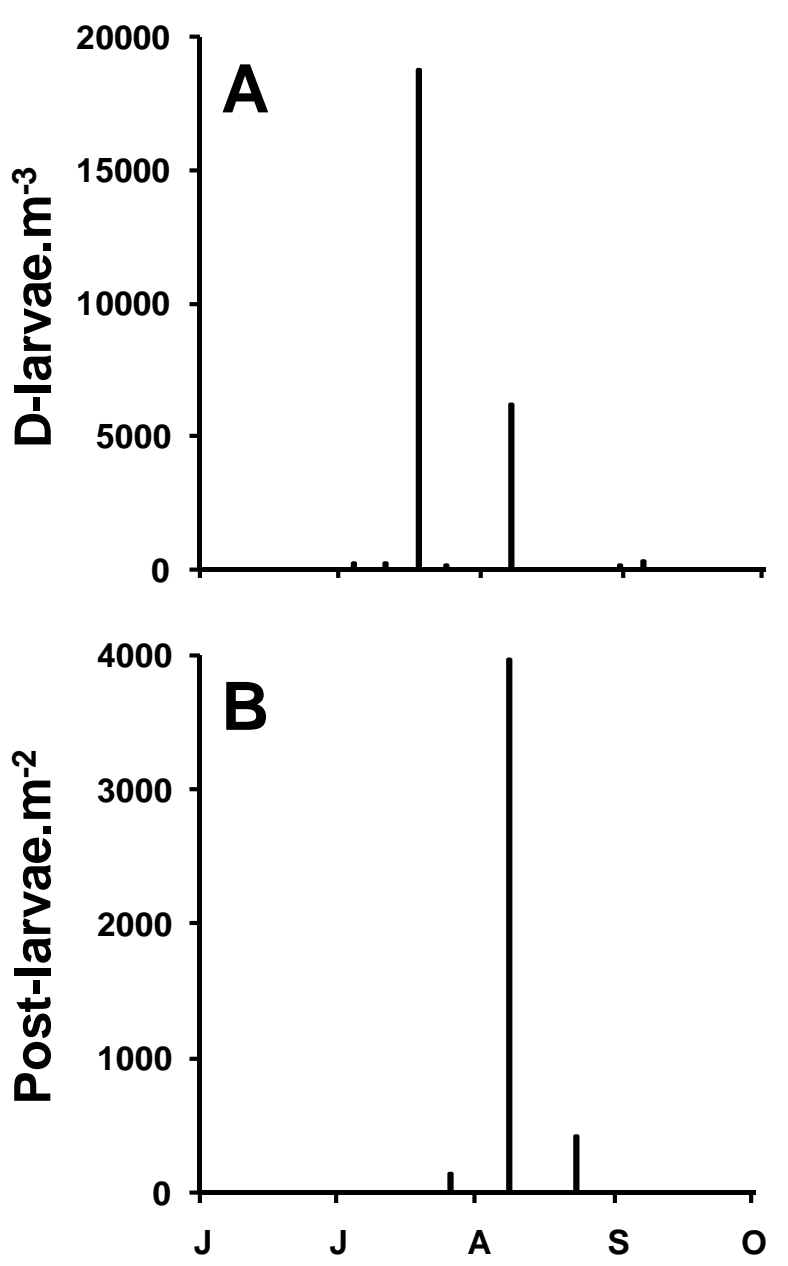

IT site
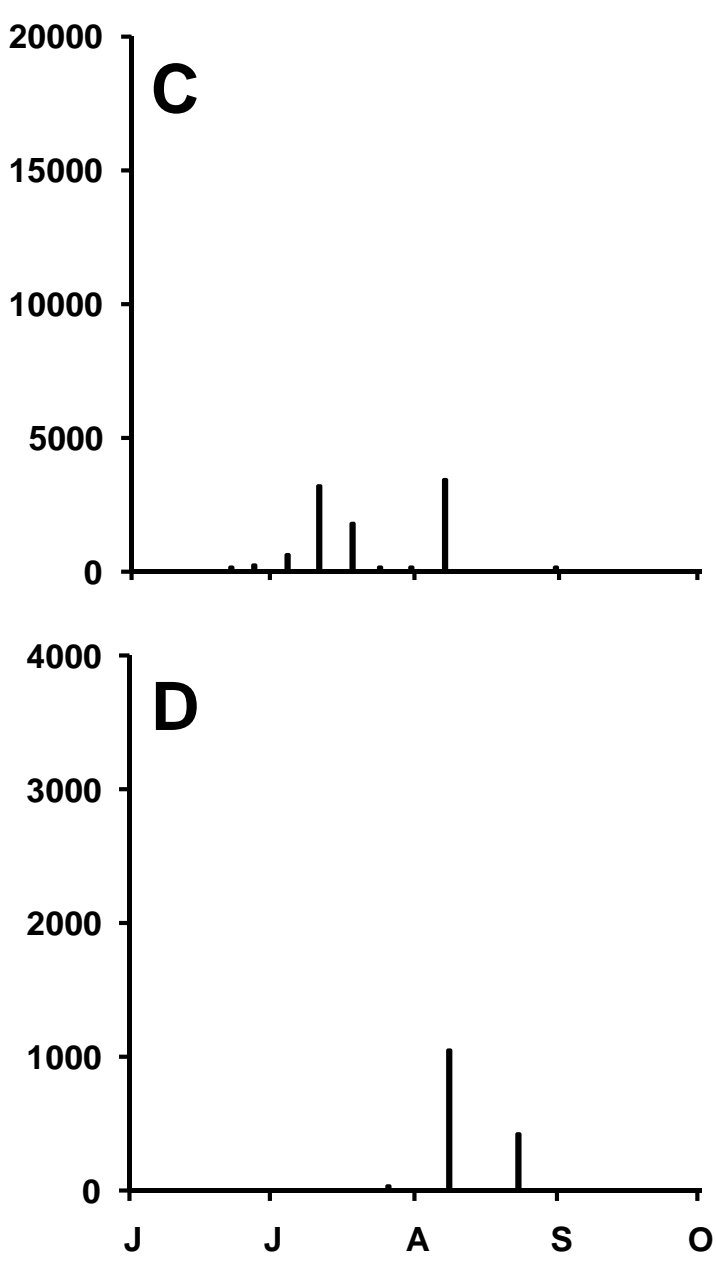

Fig. 7. D-larva $(A, C)$ and post-larval $(B, D)$ densities at the northern high turbidity

$570(\mathrm{HT})$ and southern intermediate turbidity (IT) sites of Bourgneuf Bay for the year

5712006. 